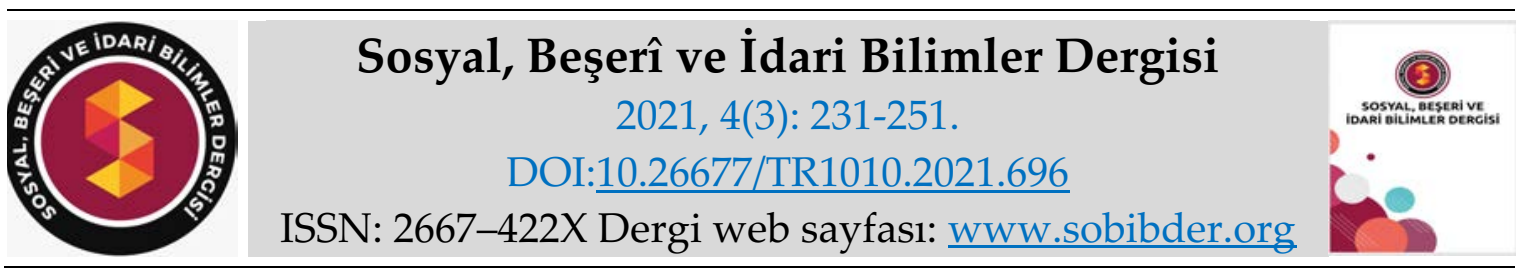

$\underline{\text { ARASTTIRMA MAKALESI }}$

\title{
Turizm Meslek Lisesi Öğrencilerinin Kişilik Özelliklerinin Kariyer Çapalarına Etkisi
}

Ömer SARI, Doktora Öğrencisi, Ankara Hacı Bayram Veli Üniversitesi, Lisansüstü Eğitim Enstitüsü, Ankara, e-posta: omersarii0680@gmail.com

ORCID: https://orcid.org/0000-0002-7611-2362

Prof. Dr. Şenol ÇAVUŞ, Sakarya Uygulamalı Bilimler Üniversitesi, Turizm Fakültesi, Sakarya, eposta: senolcavus@subu.edu.tr

ORCID: https://orcid.org/0000-0002-1994-9721

Öz

Kişilik özellikleri, bireyin birçok tutumunu etkilediği gibi kariyer çapalarına yönelik tutumlarını da etkilemektedir. Kişilik özellikleri ve bireyin kariyer çapalarına yönelik tutumları, kişinin iş yaşamındaki mutluluğuna etki ettiği gibi sektördeki verimliliğe de katkı sağlamaktadır. Emek yoğun sektörlerde, ürünün elde edilme sürecinin neredeyse tamamının insan faktörü olması nedeniyle bu husus daha çok önem arz etmektedir. Beşeri bir sektör olan turizm sektörü de insan faktörünün yoğun olduğu bir sektördür. Turizm sektörüne hem ara eleman yetiştiren hem de yükseköğrenime geçişte önemli bir program olan turizm meslek liseleri bu hususta oldukça büyük öneme sahiptir. Bu çalışmanın amacı turizm meslek liselerinde öğrenim gören öğrencilerin kişilik özelliklerinin kariyer çapaları üzerinde bir etkisi olup olmadığını belirlemeye yöneliktir. Bu kapsamda araştırma, anket tekniği kullanılarak 190 öğrenci üzerinde gerçekleştirilmiştir. Elde edilen sonuçlar çoklu doğrusal regresyon analizi ile yorumlanmıştır. Analiz sonucunda, kişilik özelliklerinin genellikle kariyer çapaları üzerinde anlamlı bir etkiye sahip olduğu tespit edilmiştir.

Anahtar Kelimeler: Kişilik Özellikleri, Kariyer Çapası, Turizm Lisesi.

Makale Gönderme Tarihi: 27.12.2020

Makale Kabul Tarihi: 11.03.2021

\section{Önerilen Atıf:}

Sarı, Ö. ve Çavuş, Ş. (2021). Turizm Meslek Lisesi Öğrencilerinin Kişilik Özelliklerinin Kariyer Çapalarına Etkisi, Sosyal, Beşeri ve İdari Bilimler Dergisi, 4(3): 231-251.

(c) 2021 Sosyal, Beşerî ve İdari Bilimler Dergisi. 


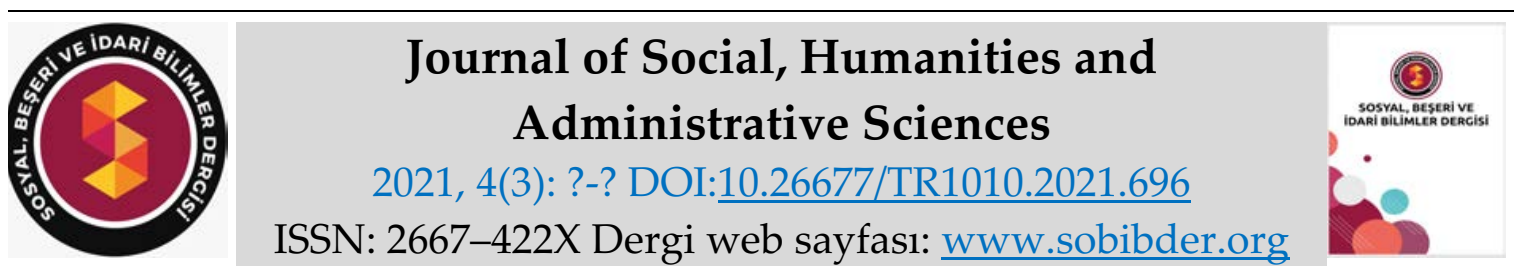

RESEARCH PAPER

\title{
The Effect of Personal Characteristics of Tourism Vocational High School Students on Career Anchors
}

Ömer SARI, Ph.D. Student, Ankara Hacı Bayram Veli University, Graduate Education Institute, Ankara, e-mail: omersarii0680@gmail.com ORCID: https://orcid.org/0000-0002-7611-2362

Prof. Dr. Şenol ÇAVUŞ, Sakarya University of Applied Sciences, Faculty of Tourism, Sakarya, email: senolcavus@subu.edu.tr ORCID: https://orcid.org/0000-0002-1994-9721

\begin{abstract}
Personality traits affect individual's attitudes towards career anchors as well as many attitudes. Personality traits and attitudes of the individual towards career anchors not only affect one's happiness in business life, but also contribute to productivity in the sector. In labor-intensive sectors, this is more important since almost the entire process of obtaining the product is the human factor. Tourism sector, which is a human sector, is also a sector where labor factor is intense. Tourism vocational high schools, which train both intermediate staff in the tourism sector and are an important and compulsory program in transition to higher education, are of great importance in this regard. The aim of this study is based on the relationship between the personality traits of students studying in tourism vocational high schools on career anchors and whether they have an effect on career anchors. In this context, the research was carried out on 190 students using the questionnaire technique. The results obtained were interpreted by multiple linear regression analysis. As a result of the analysis, it was found that personality traits generally have a significant effect on career anchors.
\end{abstract}

Keywords: Personality Traits, Career Anchor, Tourism High School.

Received: 27.12 .2020

Accepted: 11.03 .2021

\section{Suggested Citation:}

Sarı, Ö. and Çavuş, Ş. (2021). The Effect of Personal Characteristics of Tourism Vocational High School Students on Career Anchors, Journal of Social, Humanities and Administrative Sciences, 4(3): 231-251.

(C) 2021 Sosyal, Beşerî ve İdari Bilimler Dergisi. 


\section{Gíriş}

Bireylerin çalışma hayatında, bilgi ve yetenekleri önemli bir yere sahiptir. Bireylerin bu yeterliliklerine sahip olmasında ise olarak kişilik özellikleri belirleyici rol üstenmektedir. Dolayısıyla, bilgi ve yeteneklerini kişilik özellikleri ile bütünleştiren bireyler çalışma hayatında birçok fırsatlar elde etmektedir (Adıgüzel, 2009: 278). Kişilik özellikleri bireylerin yaşadığ1 toplumlarda birçok unsurun seçiminde etkili olmaktadır. Özellikle iş yaşamında karşımıza çıkan kişilik özellikleri, bireylerin verimliliğine ve mutluluğuna doğrudan katkı sağlaması kaçınılmazdır. Kişilerin çalışma yaşamında karşılaştığı işe ilişkin rolleri, etkinlikleri ve deneyimler dizisi bireylerin kariyerlerinin oluşmasına ortam hazırlamaktadır (Arnold, 1997: 16).

Kişiye özgü özelliklerin kombinasyonu olan kariyer değerleri, bireylerin kariyer planlama sürecinde önemli bir yere sahiptir (Schein, 1980: 78). Dolayısıyla bireyin kişilik özellikleri, kariyer çapalarına yönelik beklentilerinde bir yargının oluşmasına ortam hazırlamaktadır. Bireylerin kişilik özelliklerinin hem kendi mutlulukları hem de çalıştıkları iş yerindeki verimlilik, iş doyumu, yaratıcılık problem çözme becerisi üzerinde etkili olduğu düşünülmektedir. Bu bağlamda bireylerin kendi kişilik özellikleri ile uyumlu meslekler seçmeleri oldukça büyük öneme sahiptir (Bayram vd., 2012: 182). Bununla birlikte bireylerin kişilik yapıları, zamanlarının büyük bir kısmını iş yerinde geçirmelerinden dolayı örgüt yapısı, kültürü ve ikliminden etkilenmektedir (Aytaç, 2001: 4). Bu noktada örgütün yapısı, kültürü ve iklimi kişilik yapısı ile uyum içinde olması arzu edilen başarının sağlanmasında kilit rol üstlenecektir (Soysal, 2008: 9).

Emek yoğun sektörlerde ürünün elde edilme sürecinin neredeyse tamamına yakın bir kısmında insan faktörünün önemi büyüktür. Hizmet sektörünün bir önemli bir kolu olan turizm sektörü de emeğin yani diğer bir ifadeyle insan faktörünün yoğun olduğu bir sektördür. Türkiye'de turizm sektörüne hem ara eleman yetiştiren hem de yükseköğrenime geçişte önemli ve zorunlu bir basamak olan turizm meslek liseleri, bireylerin iş yaşamındaki mutluluğunun sağlanması ve turizm gelişimi açısından oldukça büyük öneme sahiptir. Söz konusu kişilik özelliklerinin kariyer çapaları üzerindeki etkisini inceleyen araştırmaların birçoğunda üniversite öğrencileri (Gezen ve Köroğlu, 2014; Ülker ve Akan, 2019) veya herhangi bir mesleğe ait meslek üyeleri üzerinde durulduğu görülmektedir (Rensburg vd., 2013). Bununla birlikte Olcay ve Düzgün (2015) turizm liselerinde okuyan öğrenciler üzerinde yaptığı bir araştırmada öğrencilerin demografik özelliklerinin kişilik özellikleri ve kariyer değerleri arasında anlamlı bir farklılık olduğunu tespit etmiştir. Bu çalışma ise Safranbolu' da turizm eğitimi veren bir lisede öğrenim gören öğrencilerin kişilik özelliklerinin kariyer beklentileri üzerinde anlamlı bir etkisinin olup olmadığı incelenmiştir. Bu yönüyle Olcay ve Düzgün (2015)'nün çalışmalarından faklı olup ilgili literatürdeki boşluğa katkı sağlayacağı düşünülmektedir.

\section{KAVRAMSAL ÇERÇEVE}

Kişilik kavramına ilişkin literatürde çok sayıda tanım mevcuttur. Bir tanıma göre kişilik, bireyi toplumdaki diğer bireylerden ayıran özellikler bütünüdür. Bir başka ifadeyle bireyin ayırt edici olan duygusal, düşünsel, ruhsal ve fiziki özelliklerinin doğumundan ölümüne kadarki süreç içerisinde yansıması kişilik olarak tanımlanmaktadır (Aytaç, 2004: 210). Kişilik kavramı ve özellikleri genellikle kişilik kuramları ile açıklanmaya çalışılmaktadır. Kişilik kuramları önceleri bireylerin benzerlikleri üzerine odaklansa da son zamanlarda yapılan araştırmalarda kişilik kuramlarının bireysel farklılıklar üzerinde yoğunlaştığı görülmektedir (McAdams, 1992: 330). Örneğin Costa ve Widiger (2013) bireysel farklılıkları bilişsel, davranışsal ve duygusal desenler bağlamında beş boyuttan oluşan bir model üzerinden açıklamıştır. Bunlar; dışadönüklük, uyumluluk, dürüstlük, nevrotiklik ve deneyime açıklık olarak ifade edilmektedir. Ayrıca dil ve 
kültürün her ulus ve toplumun kişilik özelliklerinin belirlenmesinde önemli bir unsur olduğu bilinmektedir (Gençöz ve Öncül, 2012: 195).

Kişilerarası ilişkileri sözü edilen model üzerinden inceleyen araştırmalarda nevrotikliğin; olumsuz etki (McFatter, 1994; Weinstock ve Whisman, 2006), endişeye yatkınlık (Tamir, 2005), kaçınma ve istekli düşünmeyi teşvik eden duygu odaklı başa çıkma stratejileri (Bouchard, 2003) gibi bir dizi değişkenle ilişkisi olduğu sonucuna ulaşılmıştır. Kişilerarası ilişkilerin dışadönüklükle ilişkisini inceleyen bir araştırmada da dışa dönük bireylerin içe dönük bireylere göre sosyal etkileşimlerinden daha olumlu olarak değerlendirdikleri tespit edilmiştir (Côté ve Moskowitz, 1998).

Başka bir çalışmada ise sorumluluk ve güvenilirlik gibi bireysel özelliklerin herhangi bir hayal kırklığına karşı problemle başa çıkmanın ilişkili olduğu ortaya konmuştur (Jensen-Campbell vd., 2002; George ve Zhou, 2001; Costa ve Widiger, 2013). Kişilerarası ilişkilerin uyumlulukla ilişkisini inceleyen Wilkowski ve arkadaşları (2006), yüksek derecede uyumlu bireylerin sosyal iletişim ve etkileşim kalitesi ve çeşitli kişilerarası stratejilerle ilişkili olduğunu tespit etmiştir. Deneyime açılık özelliğinde ise başlangıçta yapılan araştırmalarda deneyime açıklığın psikolojik açıdan iyi olmaya katkı sağladığı sonucuna varılsa da son yapılan çalışmalarda, problemlerle başa çıkma konusuna psikolojik açıdan olumlu katkı sağladığı sonucu rapor edilmiştir (Bouchard, 2003).

Kişilik özellikleri, bireylerin sosyal yaşamında olduğu gibi iş yaşamında da önemli olan özelliklerin değerlendirilmesinde kullanılmaktadır (Demirbilek, 2010: 1). Aytaç (2004: 224)'a göre her bireyin istek, ihtiyaç ve hırsları kişiye göre farklılık gösterebilir ve buna bağlı olarak bireyin iş yaşamında aldığı görev ve sorumlulukları yerine getirmede farklılıklar oluşabilir. Dolayısıyla bireyin sahip olduğu kişilik yapısının iş başarısı ve kalitesinde etkili olduğu düşünülmektedir. $\mathrm{Bu}$ yönde yapılan araştırmalar kişilik yapılarının iş doyumuna, kariyer doyumuna, motivasyona, işten ayrılma niyetine, takım çalışmasına, iş yeri bağlılığına, performans gibi bir dizi davranışı yerine getirme hususunda olumlu sonuçlar verdiğini göstermektedir. İnsan hayatının büyük bir bölümünü çalışarak geçirmektedir. Kişilerin iş yaşamında mutlu olmasının kişilik özelliğiyle uyumlu bir meslek seçmesine bağlı olduğu düşünülmektedir (Pilavcı, 2007: 2).

Meslek seçiminde belirleyici unsur haline gelen kariyer çapaları, günümüzde araştırmacılar tarafından sıklıkla araştırılan konular arasında yer almaktadır. Kariyer çapaları, kişinin kendi kendine algıladığı; temel değerleri, yetenek ve becerileri, güdü ve ihtiyaçlardan oluşan benlik kavramı olarak ifade edilmektedir. Bireye has özelliklerden oluşan bu bileşenler, kişilerin kariyer seçiminde etkili olmaktadır (Schein, 1980: 78). Schein'a göre, kariyer değerleri kişinin sosyal ve iş yaşamından elde ettiği tecrübeler sayesinde gelişir (Evans, 1996; Yahong vd., 2006; Marshall ve Bonner 2003; Adıgüzel, 2009; Bigliardi ve Alberto, 2009) ve bu değerlerin kişi tarafından bilinmesi hali kariyer seçimini önemli oranda şekillendirir (Peterson ve Roger 2009: 2).

Schein yaptığı araştırma ve incelemeler sonucunda ilk olarak beş temel kariyer değeri olduğunu ileri sürmüşse de daha sonra yaptığı incelemelerle üç kariyer değeri daha ekleyerek toplamda sekiz temel kariyer değeri olduğunu belirtmiştir (Shin, 2001; Wynne, 2002; Danziger ve Valency, 2006; Pilavc1, 2007; Danziger vd., 2008; Adıgüzel, 2009; Koca, 2009).

Shein'in geliştirdiği bu kariyer değerlerine sahip bireylerin özellikleri şu şekilde açıklanmıştır. Teknik/fonksiyonel, kariyer değerini temsil eden bireylerin başarılı oldukları konu hakkında uzmanlaşmaya gittikleri ve uzmanlaştıkları branşta ise en iyi olmak için mücadele ettikleri ifade edilmektedir. Güvenlik/istikrar, değerini temsil eden bireylerin geleceklerinin garanti altında olmasını talep ettikleri düşünülmektedir. Özerklik/bağımsızlık, değerini temsil eden bireylerin özgürlüklerine önem verdiklerini ve buna bağlı olarak kendilerine ne yapılacağının söylenmesinden rahatsızlık duydukları ile açıklanmaktadır. Yönetsel yetkinlik, değerini temsil eden bireylerin problem çözme konusunda başarılı oldukları sosyal ve duygusal denge 
konusunda yetenekli olduklarıyla açılanabilir. Girişimcilik/yaratıcılık, değerini temsil eden bireylerin üretken ve kendi işlerini yapma eğiliminde oldukları görülmektedir. Meydan okuyucu, değerini temsil eden bireylerin rekabetçi ve zorluklara göğüs gererek kazanmayı arzulama eğiliminde oldukları ifade edilmektedir. Kendini adama, değerini temsil eden bireylerin iş hayatında toplumu ve dünyayı geliştirme eğilimi olduklarıyla açıklanabilir. Hayat tarzı ise değerini temsil eden bireylerin özel hayatları ile iş yaşamı arasında bir denge kurmayı amaçlama eğiliminde oldukları ifade edilmektedir (Schein, 1980; Bayram vd., 2012: 182).

Bireylerin kariyer değerlerine bağlı olarak iş hayatındaki başarıları, kişilik tipleriyle doğrudan ilişkilidir (Soysal, 2008: 9). Söz konusu bu ilişkinin kişilerin kariyer değerlerinin belirlenmesine rehberlik edeceği düşünülmektedir (Schreuder ve Coetzee, 2002: 53). Kişilik özellikleri ile kariyer değeri arasında inceleme yapan bazı çalı̧̧malar şu şekildedir:

Jarlström (2000) kişilik özellikleri ile kariyer değerlerine yönelik beklentiler arasındaki ilişkiyi Finlandiya'da işletme bölümü öğrencileri üzerinde yaptı̆̆ı araştırmada incelemiş ve kişilik özellikleri ile kariyer beklentileri arasında anlamlı ilişkiler olduğunu ortaya koymuştur. Seibert ve Kraimer (2001) beş faktör kişilik özellikleri ile kariyer değerlerine yönelik beklentiler arasındaki ilişkiyi çeşitli meslek grupları üzerinde incelediği bir çalışmada, beş faktör kişilik özellikleri ile kariyer değerleri arasında negatif bir ilişki olduğu sonucuna ulaşmıştır.

Van Rensburg ve arkadaşları (2003) kişilik özellikleri ile kariyer değerlerine yönelik beklentiler arasındaki ilişkiyi belirlemek üzere eczacılar üzerinde yaptıkları araştırmada, katılımcıların kişilik özellikleri ile kariyer beklentileri arasında anlamlı ilişkiler olduğunu ortaya koymuştur. Serinkan ve Barutçu (2006) kişilik özellikleri ile kariyer değerlerine yönelik beklentiler arasında demografik değişkenler bakımından farklılık olup olmadığını incelendikleri bir araştırmada, öğrencilerin kişilik özelliklerinin cinsiyete göre anlamlı olarak farklılaştığı, buna karşın kariyer değerlerine yönelik beklentilerinde cinsiyete göre anlamlı bir farklılık olmadığını tespit etmişlerdir.

Gunkel ve arkadaşları (2010) kişilik özelliklerinin kariyer değerlerine yönelik beklentiler üzerindeki etkisini Çin, Almanya ve ABD'de öğrenim gören işletme bölümü öğrencileri üzerinde yaptıkları bir çalışmada, kişilik özelliklerinin kariyer kararlılığı ve faktörleri üzerinde doğrudan ve olumlu etkileri olduğunu ortaya koymuşlardır. Ayrıca, incelenen üç ülkede kişiliğin ve kariyer kararlılı̆̆ının öncüllerinin etkisinin ülkelere göre farklı olduğu sonucuna ulaşılmıştır. Kişilik özelliklerinin kariyer değerlerine yönelik beklentiler üzerindeki etkisinin araştırıldığ 1 başka bir çalışmada (Bayram vd., 2012) bir devlet üniversitesinin farklı bölümlerinde öğrenim gören öğrencilerin görüşleri değerlendirilmiştir. Çalışmada kız ve erkek öğrenciler arasında anlamlı bir farklılık olduğu ve öğrencilerin kişilik özelliklerinin kariyer beklentileri üzerinde anlamlı bir etkisi olduğu ortaya konmuştur.

Bir devlet, bir vakıf üniversitesinde öğrenim gören öğrencilerin kişilik özelliklerinin kariyer değerlerine yönelik beklentileri üzerindeki etkisinin araştırıldığ başka bir çalışmada ise (Başol ve arkadaşları, 2015) öğrencilerin kişilik özelliklerinin kariyer değerlerine yönelik beklentileri üzerindeki etkinin öğrencilerin okudukları üniversiteye göre anlamlı olarak farklı olduğu tespit edilmiştir. İçerli ve Uğuz Arsu (2019) tarafından Aksaray Üniversitesi İktisadi ve İdari Bilimler Fakültesi'nde okuyan öğrenciler üzerinde yapılan benzer bir çalışmada da beş faktör kişilik boyutları ile kariyer değerleri arasında pozitif yönlü anlamlı bir ilişki olduğu sonucu ortaya çıkmıştır. Sonuç olarak literatürden elde edilen temel çıkarım, kişilik özelliklerinin kariyer değerlerine yönelik eğilimleri önemli ölçüde ilişkili ve etkili olduğu görülmektedir. 


\section{ARAŞTIRMANIN YÖNTEMI}

Araştırma, neden sonuç ilişkilerinin belirlemek amacıyla bağımsız değişkenin bağımlı değişken üzerindeki etkisine yönelik araştırma modeli olan deneme modeliyle (İslamoğlu ve Alnıaçık, 2016:101) yürütülmüştür. Bununla birlikte çalışmada öğrencilerden konu ile ilgili doğru, güvenilir ve geçerli olacak şekilde kişisel görüşlerin alınmasını sağlayan (Arıkan, 2013: 60) nicel araştırma yönteminden anket tekniği uygulanmıştır.

\section{Evren ve Örneklem}

Turizm sektörüne hem ara elaman yetiştiren hem de yükseköğrenime geçişte zorunlu bir eğitim basamağı olan turizm liseleri oldukça büyük öneme sahiptir. Türkiye'de lise düzeyinde turizm eğitimi veren okullar, Milli Eğitim Bakanlığı bünyesinde Mesleki ve Teknik Anadolu Liseleri ve Çok Programlı Anadolu Liselerinde yürütülmektedir (Milli Eğitim Bakanlığı, 2015). Konaklama ve seyahat hizmetleri ile yiyecek ve içecek hizmetleri alanında eğitim veren orta öğretim düzeyindeki bu eğitim kurumlarının sağladığı eğitim kalitesi oldukça önemlidir. Bu nedenle araştırma, T.C. Milli Eğitim Bakanlığı ve T.C. Kültür ve Turizm Bakanlığıyla imzaladığı protokol sayesinde 2020 yılında proje okulu statüsüne geçerek eğitim kalitesini arttırmayı hedefleyen Safranbolu Evliya Çelebi Mesleki ve Teknik Anadolu Lisesinde yapılmıştır. Safranbolu Evliya Çelebi Mesleki ve Teknik Anadolu Lisesi konuyla ilgili 2020 yılının şubat ayında öğrencilerine bilgilendirme toplantısı düzenlemiştir (EÇMTAL, 2020). Araştırmanın evreni, yıl ve ay seçimi, bu bilgiler referans alınarak yapılmıştır. Dolayısıyla çalışma, 2020 yılının Şubat ayında gerçekleşmiştir. Araştırmaya, evrende bulunan katılımcı sayısı görece olarak az sayıda birimden oluştuğu zamanlarda tamsayıma gitmek daha makul bir çözüm (Nakip, 2003:175) olduğundan Safranbolu Evliya Çelebi Mesleki ve Teknik Anadolu Lisesinde öğrenim gören 190 öğrencinin tamamı dahil edilmiştir.

\section{Veri Toplama Araçları ve Verilerin Toplanması}

Çalışmada kullanılan anket formunda öğrencilere ait çeşitli sosyo-demografik değişkenlerin yanı sıra kariyer değerleri ölçeği ve temel kişilik özellikleri ölçeği uygulanmıştır. Öğrencilerin kariyer değerlerine yönelik beklentilerini tespit etmek amacıyla Edgar Schein (1990)'in bireylerin kariyer değerlerini belirlemek için geliştirdiği 36 maddelik "Kariyer Çapaları Ölçeği" kullanılmıştır. Dilin ve kültürün her ulus ve toplumun kişilik özelliklerinin belirlenmesinde önemli bir unsur olduğunu ifade eden Gençöz ve Öncül (2012) Türklerin kişilik özelliklerinin tespit edilmesine yönelik yaptığı bir araştırmada beş boyutlu kişilik modeline ek olarak dürüstlük boyutunu da eklemiştir. Dolayısıyla bireyleri ayırt etme imkanı tanıyan kişilik özelliklerinde dürüstlügün de önemli bir kriter olduğu kabul edilmektedir. Bu sebeple öğrencilerin kişilik özelliklerini belirlemek için ise Gençöz ve Öncül (2012) tarafından geliştirilen ve 44 ifadeden oluşan "Temel Kişilik Özellikleri" ölçeği kullanılmıştır. Araştırma kapsamında kişilik özellikleri ve kariyer çapasında yer alan ifadeler "1: Hiç önemli değil”, “5: Çok önemli” şeklinde 5’li Likert tipi ölçekle değerlendirilmiştir. Araştırma sürecinde anketler, söz konusu okulun okul müdüründen izin alınarak yürütülmüştür. Bununla birlikte anketler öğrencilerle yüz yüze gerçekleştirilmiştir.

\section{Verilerin Analizi}

Verilerin analiz edilmesinde istatistik programından yararlanılmıştır. İlk olarak araştırma kapsamında kullanılan ölçeklerin güvenilirlik analizi yapılmış, ardından araştırmaya katılan 
öğrencilerin demografik özellikleri frekans analizi değerlendirilmiş ve ölçeklere faktör analizi uygulanmıştır. Son olarak çoklu doğrusal regresyon analizi yapılmıştır.

Tablo 1. Güvenilirlik Analizi

\begin{tabular}{lcc}
\hline Değişkenler & İfade sayısı & Cronbach's Alpha değerleri \\
\hline Kişilik Özelliği Ölçeği & $\mathbf{4 1}$ & $\mathbf{0 , 7 8 6}$ \\
\hline Dişadönüklük & 6 & 0,884 \\
\hline Dürüstlük & 7 & 0,813 \\
\hline Uyumluluk & 8 & 0,956 \\
\hline Nevrotiklik & 9 & 0,912 \\
\hline Deneyime açıklık & 5 & 0,922 \\
\hline Negatif değerlik & 6 & 0,907 \\
\hline Kariyer Çapa Ölçeği & $\mathbf{3 2}$ & $\mathbf{0 , 8 4 8}$ \\
\hline Teknik fonksiyonel yetkinlik & 5 & 0,620 \\
\hline Güvenlik/İstikrar & 4 & 0,892 \\
\hline Özerklik/Otonomi & 4 & 0,600 \\
\hline Girişimcilik & 5 & 0,877 \\
\hline Hizmet veya Bir Olaya Kendini Adamak & 5 & 0,602 \\
\hline Saf Meydan Okuma & 5 & 0,877 \\
\hline Hayat Tarzı & 4 & 0,607 \\
\hline Ölçek & $\mathbf{7 3}$ & $\mathbf{0 , 8 6 6}$ \\
\hline
\end{tabular}

Tablo 2. Demografik Özellikler

\begin{tabular}{|c|c|c|c|}
\hline \multicolumn{2}{|c|}{ Demografik Özellikler } & $\mathrm{n}$ & $\mathrm{F}$ \\
\hline \multirow[t]{2}{*}{ Cinsiyet } & Kadın & 70 & 36,8 \\
\hline & Erkek & 120 & 63,2 \\
\hline \multirow[t]{5}{*}{ Yaş } & 15 & 47 & 24,7 \\
\hline & 16 & 47 & 24,7 \\
\hline & 17 & 52 & 27,4 \\
\hline & 18 & 23 & 12,1 \\
\hline & 19 & 21 & 11,1 \\
\hline \multirow[t]{4}{*}{ Sinif } & 9. Sinif & 47 & 24,7 \\
\hline & 10. Sinif & 51 & 26,8 \\
\hline & 11. Sinif & 39 & 20,5 \\
\hline & 12. Sinif & 51 & 26,8 \\
\hline \multirow[t]{3}{*}{ Bölüm } & Konaklama Hizmetleri & 63 & 33,2 \\
\hline & Yiyecek İçecek Hizmetleri & 76 & 40,0 \\
\hline & Henüz Bölüm Seçmedim & 51 & 26,8 \\
\hline \multirow{3}{*}{$\begin{array}{l}\text { Mezun olduktan sonra mesleği yapma } \\
\text { isteği }\end{array}$} & Evet & 98 & 51,6 \\
\hline & Hayır & 20 & 10,5 \\
\hline & Belki & 72 & 37,9 \\
\hline \multirow[t]{3}{*}{ Okulu seçiminizde etkili olan durum } & İsteyerek Seçtim & 129 & 67,9 \\
\hline & Kısmen İsteyerek Seçtim & 46 & 24,2 \\
\hline & İstemeyerek Seçtim & 15 & 7,9 \\
\hline \multirow{5}{*}{$\begin{array}{l}\text { Turizm lisesi okumaktan memnun } \\
\text { olma durumu }\end{array}$} & Hiç Memnun Değilim & 7 & 3,7 \\
\hline & Memnun Değilim & 16 & 8,4 \\
\hline & Memnunum & 63 & 33,2 \\
\hline & Kismen Memnunum & 44 & 23,2 \\
\hline & Çok Memnunum & 60 & 31,6 \\
\hline
\end{tabular}


Araştırma kapsamında kullanılan ölçeklerin güvenilirlik analizi Tablo 1'de gösterilmektedir. Buna göre kişilik özellikleri $(0,786)$; dışadönüklük $(0,884)$, dürüstlük $(0,813)$, uyumluluk $(0,956)$, nevrotiklik $(0,912)$, deneyime açılık $(0,922)$ ve negatif değerlik $(0,907)$ Cronbach's Alpha katsayıları bulunmuştur. Kariyer çapası $(0,848)$ boyutları ise teknik fonksiyonel yetkinlik $(0,620)$, güvenlik/istikrar $(0,892)$, özerklik/otonomi $(0,600)$, girişimcilik $(0,877)$, hizmet veya bir olaya kendini adamak $(0,602)$, saf meydan okuma $(0,877)$ ve hayat tarzı $(0,607)$ Cronbach's Alpha katsayıları bulunmuştur. Ayrıca oluşturulan ölçeğin genel güvenilirlik değeri $\alpha=0,866$ şeklinde elde edilmiştir. Elde edilen bu katsayılar, ölçeğin güvenilir olduğunu ve literatürde genel kabul görebileceğini (Kalayc1, 2010:405) göstermektedir.

Araştırma evreninde yer alan öğrencilerin demografik özelliklerine yönelik frekans dağılımları Tablo 2'de gösterilmektedir. Frekans dağılımına göre araştırma evreninde yer alan öğrencilerin $\% 63,2^{\prime}$ si erkek, \%27,4'ü 17 yaşında, \%26,8 eşit oranda 10. ve 12. sınıfta, $\% 40,0^{\prime} 1$ yiyecek içecek hizmetleri bölümünde öğrenim görmektedir. Ayrıca öğrencilerin \%51,6'sının mezun olduktan sonra mesleğini yapma isteğinde olduğu, \%67,9'unun okulu isteyerek seçtikleri ve \%33,2'sinin turizm lisesinde okumaktan memnun oldukları görülmektedir.

\section{BULGULAR}

Araştırma kapsamında kullanılacak analiz türlerini belirlemek üzere verilere normallik analizi yapılmıştır. Normallik analizinde, araştırma verilerinin çarpıklık (skewness) ve basıklık (kurtosis) değerleri dikkate alınmıştır. Tabachnick ve Fidell (2001)'e göre çarpıklık ve basıklık değerlerinin $\pm 1,96$ değerleri aralığında olması, verilerin normal dağıldığını göstermektedir. Tablo 3’de görüldüğü üzere verilerin normal dağılım gösterdiği sonucu elde edilmiştir.

Tablo 3. Normallik Testi

\begin{tabular}{|c|c|c|c|}
\hline & DEĞIŞKENLER & ÇARPIKLIK & BASIKLIK \\
\hline \multirow{6}{*}{$\begin{array}{l}\text { Kişilik } \\
\text { Özellikleri }\end{array}$} & Dişadönüklük & 1,172 & 0,550 \\
\hline & Uyumluluk & $-0,510$ & $-0,653$ \\
\hline & Nevrotiklik & 0,314 & $-1,107$ \\
\hline & Dürüstlük &, 003 & $-1,164$ \\
\hline & Negatif değerlik & 1,849 & 1,479 \\
\hline & Deneyime açıklık & $-0,421$ & $-0,757$ \\
\hline \multirow{7}{*}{ Kariyer Çapası } & Teknik fonksiyonel yetkinlik & $-0,150$ & $-0,997$ \\
\hline & Güvenlik/İstikrar & $-0,100$ & $-0,820$ \\
\hline & Özerklik/Otonomi & $-0,035$ & $-0,868$ \\
\hline & Girişimcilik & $-0,265$ & $-0,581$ \\
\hline & $\begin{array}{l}\text { Hizmet veya Bir Olaya Kendini } \\
\text { Adamak }\end{array}$ & $-0,069$ & $-0,809$ \\
\hline & Saf Meydan Okuma & $-0,142$ & $-0,909$ \\
\hline & Hayat Tarzı & $-0,159$ & $-0,614$ \\
\hline
\end{tabular}

Verilerin faktör analizine uygunluğu, değişkenler arasındaki korelasyon değerleri, Barlett küresellik testi ve Kaiser-Mayer-Olkin (KMO) uygunluk ölçütü, ortak varyans (communality) değerleri ve ölçek ifade değerleriyle değerlendirilmiştir. Çoğunlukla faktörlerin birbirleriyle ilişkili olmadığı veya güçlü ilişkiye sahip olmadığı durumlarda rotasyon metodundan eğik döndürme analizi olan direct oblimin seçimi uygundur (Tabachnick ve Fidell, 2015: 644). Bununla 
birlikte ölçek ifade değerleri 0,40'tan düşük olmamalı (Field, 2000:434) ve faktörlere dağılan ifade sayısının birden fazla olması beklenmektedir (Tabachnick ve Fidell, 2015: 618).

Tablo 4. Kişilik Özellikleri Ölçeği Faktör Analizi

\begin{tabular}{|c|c|c|c|c|}
\hline FAKTÖRLER & $\begin{array}{c}\text { Temel Kişilik } \\
\text { Özelliklerine Yönelik } \\
\text { İfadeler }\end{array}$ & $\begin{array}{l}\text { Faktör } \\
\text { yükü }\end{array}$ & Varyans & Özdeğer \\
\hline \multirow{6}{*}{ Dişadönüklük } & 1. Ürkek (Çekingen) & 879 & \multirow{6}{*}{7,699} & \multirow{6}{*}{3,234} \\
\hline & 2. İçine kapanık & 821 & & \\
\hline & 3. Utangaç & 821 & & \\
\hline & $\begin{array}{ll}\text { 4. } & \begin{array}{l}\text { Uyuşukluk } \\
\text { (Durgun) }\end{array} \\
\end{array}$ & ,716 & & \\
\hline & 5. Soğuk & 602 & & \\
\hline & 6. $\quad$ Pasif & 657 & & \\
\hline \multirow{7}{*}{ Dürüstlük } & $\begin{array}{ll}\text { 7. Öz disiplinli } \\
\text { (Disiplinli) }\end{array}$ & ,745 & \multirow{7}{*}{13,602} & \multirow{7}{*}{5,713} \\
\hline & 8. Düzenli & 790 & & \\
\hline & 9. Çalışkan & ,794 & & \\
\hline & 10. İhtiyatlı (Tedbirli) & ,793 & & \\
\hline & 11. Telaşlı (Titiz) & 693 & & \\
\hline & 12. Kararlı (Azimli) & ,770 & & \\
\hline & $\begin{array}{ll}\text { 13. } & \begin{array}{l}\text { Sorumsuz } \\
\text { (Sorumsuz) }\end{array}\end{array}$ &, 506 & & \\
\hline \multirow{8}{*}{ Uyumluluk } & 14. Samimi (İçten) & ,790 & \multirow{8}{*}{22,487} & \multirow{8}{*}{9,445} \\
\hline & 15. Şefkatli (Sevecen) & 869 & & \\
\hline & 16. Cana yakın & 896 & & \\
\hline & $\begin{array}{l}\text { 17. İyi niyetli (İyi } \\
\text { niyetli) }\end{array}$ & 872 & & \\
\hline & $\begin{array}{ll}\text { 18. } & \begin{array}{l}\text { Hayırsever } \\
\text { (Yardımsever) }\end{array}\end{array}$ & 893 & & \\
\hline & $\begin{array}{ll}\text { 19. } & \text { Toleranslı } \\
\text { (Hoşgörülü) }\end{array}$ & 876 & & \\
\hline & 20. Paylaşımcı) & ,798 & & \\
\hline & 21. Hassas (Duyarlı) & ,737 & & \\
\hline \multirow{9}{*}{ Nevrotiklik } & 22. Sinirli & , 830 & \multirow{9}{*}{15,923} & \multirow{9}{*}{6,687} \\
\hline & 23. Agresif & 867 & & \\
\hline & 24. Kizgin & ,884 & & \\
\hline & 25. Mizaç (Huysuz) &, 740 & & \\
\hline & 26. Sabirsiz & 659 & & \\
\hline & 27. Kaprisli & ,714 & & \\
\hline & 28. Aceleci & ,740 & & \\
\hline & 29. Alıngan) & ,568 & & \\
\hline & 30. Endişeli (Kaygılı) &, 532 & & \\
\hline \multirow{5}{*}{$\begin{array}{l}\text { Deneyime } \\
\text { Açıklık }\end{array}$} & 31. Kendinden emin & 862 & \multirow{5}{*}{5,788} & \multirow{5}{*}{2,431} \\
\hline & 32. Kendine güvenen & ,918 & & \\
\hline & 33. Cesur & 891 & & \\
\hline & 34. Yaratic1 & ,856 & & \\
\hline & 35. Kabiliyetli & ,725 & & \\
\hline \multirow{6}{*}{$\begin{array}{l}\text { Negatif } \\
\text { Değerlik }\end{array}$} & $\begin{array}{ll}\text { 36. } & \text { Kötü huylu } \\
\text { (Görgüsüz) }\end{array}$ & 782 & \multirow{6}{*}{4,279} & \multirow{6}{*}{1,797} \\
\hline & 37. İddialı (Yapmacık) & 818 & & \\
\hline & 38. Terbiyesiz & 830 & & \\
\hline & 39. İçten pazarlıklı & 833 & & \\
\hline & 40. Açgözlü & ,781 & & \\
\hline & 41. Sabit fikirli & 662 & & \\
\hline
\end{tabular}

Toplam Varyans: 69,779 ; Çıkarım Yöntemi: Temel Bileşenler Analizi, Rotasyon Metodu: Direct Oblimin; KMO: ,827; Barlett ki-kare: 7217,360; df: 861; Sig.: ,000 
Örnekleme yeterliliğini ölçmede kullanılan Kaiser Normalleştirmesi 0,60'nın büyük olması önerilmektedir. Modelin geçerliliğini test etmek ve değişkenler arasındaki ilişkinin 0'dan faklı olup olmadığını test etmede Barlett Küresellik testinin $(p<0,05)$ anlamlı çıkması beklenmektedir (İslamoğlu ve Alnıaçık, 2016: 416). Ayrıca faktörlerin açıklama yüzdelerinin 0,50' den fazla olması, yapılan faktör analizinin geçerli olabileceğini göstermektedir (Scherer vd., 1988). Araştırma kapsamında kullanılan ölçeklerin sahip olduğu alt boyutları tespit etmek amaciyla Tablo 4 ve 5 'de görüldüğü üzere keşfedici faktör analizi yapılmıştır.

Kişilik özelliği ölçeği faktör analizi sonuçlarına göre kişilik özelliklerinin 6 boyut altında toplandığı görülmektedir. Elde edilen bu boyutların; dışadönüklük (6 ifade), dürüstlük (6 ifade), uyumluluk ( 8 ifade), nevrotiklik ( 9 ifade), deneyime açılık (5 ifade) ve negatif değerlik (6 ifade) şeklinde oluştuğu görülmektedir. Analiz sonucunda, faktör yükleri $0,40^{\prime}$ tan düşük olan 1 ifade ve faktörlerde tek ifade olarak yer alan 2 ifade analiz dışında bırakılmıştır. Özdeğeri 1'den büyük olan 6 faktör (Bkz. Tablo 4) toplam varyansın \%69,779'unu açıklamaktadır.

Kariyer çapa ölçeği faktör analizi sonuçlarına göre kariyer çapalarının 7 boyut altında toplandığ görülmektedir. Elde edilen bu boyutların; teknik fonksiyonel yetkinlik ( 5 ifade), özerklik/otonomi (4 ifade), güvenlik/istikrar (4 ifade), girişimcilik (5 ifade), hizmet veya bir olaya kendini adamak (5 ifade), saf meydan okuma (5 ifade) ve hayat tarzı (4 ifade) şeklinde oluştuğu görülmektedir.

Tablo 5. Kariyer Çapa Ölçeği Faktör Analizi

\begin{tabular}{|c|c|c|c|c|}
\hline $\begin{array}{l}\text { FAKTÖR } \\
\text { LER }\end{array}$ & Kariyer Çapalarına Yönelik İfadeler & $\begin{array}{l}\text { Faktör } \\
\text { yükü }\end{array}$ & Varyans & Özdeğer \\
\hline \multirow{5}{*}{$\begin{array}{l}\text { Teknik } \\
\text { Fonksiyonel } \\
\text { Yetkinlik }\end{array}$} & $\begin{array}{l}\text { Özel yeteneklerimi kullanabildiğim zaman işimde başarılı } \\
\text { olurum. }\end{array}$ & ,794 & \multirow{5}{*}{5,243} & \multirow{5}{*}{1,730} \\
\hline & $\begin{array}{l}\text { Teknik /fonksiyonel becerilerimi yüksek bir yetkinlik düzeyinde } \\
\text { geliştirebilirsem kariyerimde başarılı hissederim. }\end{array}$ & 847 & & \\
\hline & $\begin{array}{l}\text { Yaptığım işte o kadar iyi olmayı hayal ederim ki aranan biri } \\
\text { olayım. }\end{array}$ &, 858 & & \\
\hline & $\begin{array}{l}\text { Uzmanlık alanımda üst düzey işlevsel bir yönetici olmak bana } \\
\text { genel müdür olmaktan daha çekici gelir. }\end{array}$ &, 814 & & \\
\hline & $\begin{array}{l}\text { Benim kendi uzmanlık alanımın dışına çıaracak dönüşümlü bir } \\
\text { görevi kabul etmektense işletmeden ayrılmayı tercih ederim }\end{array}$ & 622 & & \\
\hline \multirow{4}{*}{$\begin{array}{l}\text { Özerklik/ } \\
\text { Otonomi }\end{array}$} & $\begin{array}{l}\text { İşimde tam özerklik ve özgürlük elde edebilirsem başarılı } \\
\text { hissederim }\end{array}$ &, 831 & \multirow{4}{*}{9,179} & \multirow{4}{*}{3,029} \\
\hline & $\begin{array}{l}\text { Bir işi kendi programıma ve yöntemime göre yapmamda } \\
\text { özgürlük sağlayacak bir kariyere sahip olmayı hayal ederim. }\end{array}$ & 892 & & \\
\hline & $\begin{array}{l}\text { Özerklik ve özgürlügüüü kısıtlayacak bir işi kabul etmektense } \\
\text { işletmeden ayrılmayı tercih ederim. }\end{array}$ &, 827 & & \\
\hline & $\begin{array}{l}\text { Bir işi kendi yöntemlerime göre kurallar ve kısıtlamalar olma } \\
\text { şansı benim için güvenlikten daha önemlidir. }\end{array}$ &, 726 & & \\
\hline \multirow{4}{*}{$\begin{array}{l}\text { Güvenlik } \\
\text { /İstikrar }\end{array}$} & Bana güvenlik ve istikrar duygusu verecek işletmelerde iş ararım. & 803 & \multirow{4}{*}{3,721} & \multirow{4}{*}{1,228} \\
\hline & $\begin{array}{l}\text { Güvenlik ve istikrar duygusunu hissetmeme izin veren bir } \\
\text { kariyere sahip olmayı hayal ederim. }\end{array}$ & ,712 & & \\
\hline & $\begin{array}{l}\text { Tam olarak mali güvenlik ve iş güvenliğine sahip olduğumu } \\
\text { hissettiğimde işimde başarılı olurum. }\end{array}$ & ,762 & & \\
\hline & $\begin{array}{l}\text { Güvenlik ve istikrar benim için özerklik ve özgürlükten daha } \\
\text { önemlidir }\end{array}$ & ,778 & & \\
\hline \multirow{3}{*}{ Girişimcilik } & $\begin{array}{l}\text { Tamamen kendi fikirlerimin ve çabalarımın bir sonucu olan bir } \\
\text { şeyi yapabildiğimde kariyerimde başarılı olurum. }\end{array}$ & ,466 & \multirow{3}{*}{26,808} & \multirow{3}{*}{8,847} \\
\hline & $\begin{array}{l}\text { Bütünüyle benim kendi ürünüm/fikrim olan bir şeyi yaratmayı } \\
\text { ya da oluşturmayı başardığımda kariyerimde başarılı olduğumu } \\
\text { hissederim. }\end{array}$ &, 518 & & \\
\hline & Kendi işletmemi kurmayı ve çalıştırmayı hayal ederim & 809 & & \\
\hline
\end{tabular}




\begin{tabular}{|c|c|c|c|c|}
\hline & $\begin{array}{l}\text { Her zaman kendi işletmemi kurmama imkan verecek fikirler } \\
\text { arayışındayımdır }\end{array}$ & 788 & & \\
\hline & $\begin{array}{l}\text { Kendi işletmemi kurmak bir başkasının işletmesinde üst düzey } \\
\text { bir yönetici pozisyonunda yer almaktan daha önemlidir. }\end{array}$ & 731 & & \\
\hline \multirow{5}{*}{$\begin{array}{l}\text { Hizmet } \\
\text { veya Bir } \\
\text { Olaya } \\
\text { Kendini } \\
\text { Adamak }\end{array}$} & $\begin{array}{l}\text { İnsanlık ve toplum gelişimine gerçekten katkı sağlayacak bir } \\
\text { kariyere sahip olmayı hayal ederim. }\end{array}$ & 648 & \multirow{5}{*}{6,660} & \multirow{5}{*}{2,198} \\
\hline & $\begin{array}{l}\text { Yeteneklerimi dünyanın yaşamak/çalışmak için daha iyi bir yer } \\
\text { olması için kullanmak benim için üst düzey yönetici olmaktan } \\
\text { daha önemlidir. }\end{array}$ & 806 & & \\
\hline & $\begin{array}{l}\text { Toplum refahına gerçek bir katkıda bulunduğumu hissettiğimde } \\
\text { kariyerimde başarılı olduğumu hissederim. }\end{array}$ & 820 & & \\
\hline & $\begin{array}{l}\text { Yeteneklerimi başkalarının hizmeti için kullanmamı } \\
\text { engelleyecek bir görevi kabul etmektense işletmeden ayrılmayı } \\
\text { tercih ederim. }\end{array}$ & 680 & & \\
\hline & $\begin{array}{l}\text { Yeteneklerimi başkalarının hizmetinde kullanabildiğim zaman } \\
\text { kariyerimde başarılı olurum. }\end{array}$ & 667 & & \\
\hline \multirow{5}{*}{$\begin{array}{l}\text { Saf } \\
\text { Meydan } \\
\text { Okuma }\end{array}$} & $\begin{array}{l}\text { Problemleri çözebileceğim ya da son derece zorlu durumlarda } \\
\text { bile kazanabileceğim bir kariyeri hayal ederim. }\end{array}$ & 623 & \multirow{5}{*}{11,373} & \multirow{5}{*}{3,753} \\
\hline & $\begin{array}{l}\text { Çözülemez problemleri çözdüğüm ya da imkansız gibi görünen } \\
\text { durumların üstesinden geldiğim zaman kariyerimde başarılı } \\
\text { olurum. }\end{array}$ & 629 & & \\
\hline & $\begin{array}{l}\text { Problem çözme fırsatı veren ya da rekabetçi becerilerimi } \\
\text { tamamen zorlayan işler ararım }\end{array}$ & 785 & & \\
\hline & $\begin{array}{l}\text { Sadece çok zorlu sorunlarla karşılaştığım ve üstesinden geldiğim } \\
\text { zaman kariyerimde başarılı olduğumu hissederim. }\end{array}$ & 811 & & \\
\hline & $\begin{array}{l}\text { Çözülemeyecek problemler üzerinde çalışmak benim için üst } \\
\text { düzey bir yönetici pozisyonunda yer almaktan daha önemlidir. }\end{array}$ & 789 & & \\
\hline \multirow{4}{*}{$\begin{array}{l}\text { Hayat } \\
\text { Tarzi }\end{array}$} & $\begin{array}{l}\text { Kişisel ve mesleki hayatın taleplerini dengelemek benim için üst } \\
\text { düzey bir yönetici pozisyonunda yer almaktan daha önemlidir. }\end{array}$ & 687 & \multirow{4}{*}{5,832} & \multirow{4}{*}{1,925} \\
\hline & $\begin{array}{l}\text { Kişisel, ailevi ve çalışma ihtiyaçlarımı birleştirmeme izin veren } \\
\text { bir kariyeri hayal ederim. }\end{array}$ & 671 & & \\
\hline & $\begin{array}{l}\text { Kişisel, ailevi ve kariyer gereksinimlerimi dengede tutabilirsem } \\
\text { hayatımda başarılı olduğumu hissederim. }\end{array}$ & 678 & & \\
\hline & $\begin{array}{l}\text { Kişisel ve ailevi bağlarımı devam ettirme yeteneğimi tehlikeye } \\
\text { atacak bir işe yerleştirilmektense işletmeden ayrılmayı tercih } \\
\text { ederim. }\end{array}$ & 819 & & \\
\hline
\end{tabular}

Analiz sonucunda, faktör yükleri 0,40'tan düşük olan 1 ifade ve faktörlerde tek ifade olarak yer alan 3 ifade analiz dışında bırakılmıştır. Özdeğeri 1'den büyük olan 7 faktör (Bkz. Tablo 5) toplam varyansın \%68,816'sını açıklamaktadır. Edgar Schein (1990) çalışmasında kariyer değerleri, 8 boyut altında toplanmıştır. Ancak bu araştırmada ise 7 boyut elde edilmiştir. Analiz sırasında çıartılan ifadeler, "genel yönetsel yetkinlik" boyutunun çıkmamasına neden olmuştur. Bu yönüyle kariyer çapalarına yönelik yapılan faktör analizi literatürdeki boyutlarla tam olarak uyumlu değildir. Diğer yandan, yapılan çalışmaların birçoğunda çalışma evreni veya örneklemin yapısı, ırk, dil, kültür, yaş, coğrafya gibi demografik etmenlerin farklı olmasından dolayı faktör yapılarının farklılaştığı görülmektedir.

Araştırma amacına uygun olarak; öğrencilerin kişilik özelliklerinin kariyer çapaları üzerinde anlamlı bir yordayıcısı olup olmadığını belirlemek için çoklu doğrusal regresyon analizleri yapılmıştır. Çoklu doğrusal regresyon analizi yapılmasında ön koşul olarak, verilerin normal dağılmasının yanı sıra otokorelasyon olmaması beklenmektedir. Modelin otokorelasyon olup olmadığını görmek için Durbin -Watson değerinin 1,5-2,5 aralığında bir değer alması beklenmektedir (Küçüksille, 2018:259-268). 
Regresyon analizinde $\mathrm{F}$ değeri ve bu değerin anlamlılık derecesi $(\mathrm{p}<0,05)$ kurulan modelin anlamlı olup olmadı ̆̆ını belirlemektedir. Regresyon modelinde bağımsız değişkenlerle açılanan varyans $\mathrm{R}^{2}$ değeri ile gösterilmektedir. Dolayısıyla bağımsız değişkenler tarafından açıklanamayan varyans, modele dahil edilmeyen başka değişkenlerin olabileceği anlamına gelmektedir. Bağımlı değişkendeki varyansın diğer bağımsız değişkenler tarafından açıklanamayan kısmına oranı, tolerans kısmıyla açıklanmaktadır. Tolerans değeri $0^{\prime}$ a ne kadar yakınsa regresyon katsayısının standart hatası o kadar artacaktır. Ayrıca varyans genişlik faktörü (VIF) değerinin 2'den büyük olması genel olarak problematik bir durum olduğuna işaret etmektedir. Bağımsız değişkenlerin değerindeki küçük değişimler tahmin edilen sonuçlarda daha büyük değişimlere neden olabilir. Dolayısıyla elde edilen sonuçların Condition Index değerleri $15^{\prime}$ den büyükse eş doğrusallık sorunu olduğu $30^{\prime}$ dan büyükse eşdoğrusallık probleminin önemli oranda büyük olduğu söylenebilir. Regresyon doğrusunun dikey kestiği sabit terimleri (constant) bulunmaktadır. Modelde bağımlı değişken ile anlamlı etkisi bulunan bağımsız değişkenlerin $\mathrm{B}$ katsayı değerleri diğer bağımsız değişkenlerin etkisi sabit tutulduğunda bir bağımsız değişkenin bir birimlik artışında bağımlı değişkendeki artış veya azalış düzeylerini göstermektedir. Analizdeki modeli oluşturan bağımlı değişken ile bağımsız değişkenler arasında doğrusal bir ilişki olması gerekmektedir (İslamoğlu ve Alnıaçık, 2016:362379).

Modeli oluşturan tüm bağımsız değişkenlerin işleme alınarak bağımlı değişkeni tahmin etme başarısı enter yöntemi ile sağlanmaktadır (Karagöz, 2019: 908). Bu kapsamda yapılan regresyon analizlerinde enter metodu uygulanmıştır. Kişilik özelliklerinin, teknik fonksiyonel yetkinliği anlamlı bir şekilde yordayıp yordamadıklarını tespit etmek için çoklu doğrusal regresyon analiz sonuçları Tablo 6'da verilmiştir.

Tablo 6. Kişilik Özelliklerinin Teknik Fonksiyonel Yetkinlik Üzerindeki Etkisi

\begin{tabular}{|c|c|c|c|c|c|c|c|c|}
\hline Bağımsız değişkenler & B katsayısı & $\mathrm{SHa}_{\mathrm{a}}$ & $\beta$ & $\mathbf{t}$ & $\begin{array}{l}\text { Condition } \\
\text { Index }\end{array}$ & Tolerance & VIF & $\mathbf{p}$ \\
\hline Sabit & 2,231 & 352 & & 6,337 & 1,000 & & &, $000^{*}$ \\
\hline Dişadönüklük (DD) &,- 405 & ,069 &,- 373 & $-5,881$ & 4,245 & 824 & 1,214 &, $000^{*}$ \\
\hline Uyumluluk (U) & ,171 & ,057 & ,205 & 3,012 & 5,015 & 711 & 1,406 &, $003^{*}$ \\
\hline Dürüstlük (D) & 226 & ,063 & ,236 & 3,607 & 8,568 & ,776 & 1,289 &, $000^{*}$ \\
\hline $\begin{array}{l}\text { Negatif değerlik } \\
\text { (ND) }\end{array}$ &,- 037 & 051 &,- 046 &,- 723 & 10,867 & ,827 & 1,209 & 470 \\
\hline $\begin{array}{l}\text { Deneyime açıklık } \\
\text { (DA) }\end{array}$ & ,127 & 048 & 166 & 2,662 & 17,096 &, 848 & 1,179 &, $008^{*}$ \\
\hline Nevrotiklik (N) &, 070 & 065 &, 076 & 1,068 & 7,294 & ,661 & 1,513 & 287 \\
\hline
\end{tabular}

Bağımlı Değişken: Teknik Fonksiyonel Yetkinlik (TFY)

Analiz sonuçlarına göre, dışadönüklük, uyumluluk, dürüstlük ve deneyime açılık değişkenleri teknik fonksiyonel yetkinliğin anlamlı birer yordayıcısıdır ( $p<.05)$. Negatif değerlik ve nevrotiklik değişkenleri ise teknik fonksiyonel yetkinliğin anlamlı birer yordayıcısı olmadığı görülmüştür (p>.05). Buna göre kişilik özellikleriyle birlikte kurulan model teknik fonksiyonel yetkinlik puanlarındaki değişimin \%39,1'ini açıklamaktadır. Teknik fonksiyonel yetkinliğin \%60,9'u ise araştırmaya dahil edilmeyen başka değişkenlerce açılanabilir. Tüm bu bulgular sonucunda aşağıdaki gibi regresyon modeli kurulabilir:

$T F Y=2,231-0,405 x D D+0,171 x U+0,226 x D-0,37 x N D+0,127 x D A+0,070 x N+$ hata 
Regresyon eşitliğinden görülebileceği gibi dışadönüklük puanlarındaki bir birimlik artışla teknik fonksiyonel yetkinliğin 0,405 birimlik azalması beklenirken, uyumluluk puanlarındaki bir birimlik artışla teknik fonksiyonel yetkinliğin 0,171 birimlik artışa, dürüstlük puanlarındaki bir birimlik artışla teknik fonksiyonel yetkinliğin 0,226 birimlik artışa ve deneyime açıklık puanlarındaki bir birimlik artışla teknik fonksiyonel yetkinliğin 0,127 birimlik artacağ 1 anlaşılmaktadır.

Kişilik özelliklerinin Güvenlik/İstikrarı anlamlı bir şekilde yordayıp yordamadıklarını tespit etmek için yapılan çoklu doğrusal regresyon analiz sonuçları Tablo $7^{\prime}$ de verilmiştir. Analiz sonuçlarına göre, negatif değerlik ve deneyime açıklık değişkenleri güvenlik/istikrarın anlamlı birer yordayıcısıdır $(\mathrm{p}<.05)$.

Tablo 7. Kişilik Özelliklerinin Güvenlik/İstikrar Üzerindeki Etkisi

\begin{tabular}{|c|c|c|c|c|c|c|c|c|}
\hline $\begin{array}{l}\text { Bağımsız } \\
\text { değişkenler }\end{array}$ & B katsayısı & $\mathrm{SHa}_{\mathrm{a}}$ & $\beta$ & $\mathbf{t}$ & $\begin{array}{l}\text { Condition } \\
\text { Index }\end{array}$ & Tolerance & VIF & p \\
\hline Sabit & 2,937 & ,357 & & 8,233 & 1,000 & & & , $000^{*}$ \\
\hline $\begin{array}{l}\text { Dişadönüklük } \\
\text { (DD) }\end{array}$ &,- 183 & ,095 &,- 144 & $-1,924$ & 3,882 & ,878 & 1,139 & ,056 \\
\hline $\begin{array}{l}\text { Negatif değerlik } \\
\text { (ND) }\end{array}$ & 138 & ,066 & 147 & 2,090 & 4,309 & ,999 & 1,001 &, $038^{*}$ \\
\hline $\begin{array}{l}\text { Deneyime açıklık } \\
\text { (DA) }\end{array}$ & 141 &, 067 & 158 & 2,105 & 10,719 & 877 & 1,140 &, $037^{*}$ \\
\hline Uyumluluk (U) & ,059 & ,086 & ,060 & 688 & 5,394 & 614 & 1,628 & ,493 \\
\hline Nevrotiklik (N) & ,140 & ,092 & ,130 & 1,528 & 7,294 & 661 & 1,513 & ,128 \\
\hline Dürüstlük (D) & 220 & ,098 & ,196 & 2,247 & 9,261 & 626 & 1,597 &, $026^{*}$ \\
\hline
\end{tabular}

Bağımlı Değişken: Güvenlik/İstikrar (G/İ)

Analiz sonuçlarına göre negatif değerlik ve deneyime açıklık değişkenleri güvenlik/istikrarın anlamlı birer yordayıcısıdır ( $\mathrm{p}<.05)$. Dışadönüklük, uyumluluk ve nevrotiklik değişkenleri ise güvenlik/istikrarın anlamlı birer yordayıcısı değildir ( $>$ >05). Buna göre kişilik özellikleriyle birlikte kurulan model güvenlik/istikrar puanlarındaki değişimin \%13,1'ini açıklamaktadır. Güvenlik/istikrarın \%86, $9^{\prime} u$ ise araştırmaya dahil edilmeyen başka değişkenlerce açıklanabilir. Tüm bu bulgular sonucunda aşağıdaki gibi regresyon modeli kurulabilir:

\section{$G / \dot{I}=2,937-0,183 x D D+0,138 x N D+0,141 x D A+0,059 x U+0,140 x N+0,220 x D+$ hata}

Regresyon eşitliğinden görülebileceği gibi negatif değerlik puanlarındaki bir birimlik artışla güvenlik/istikrarın 0,138 birimlik artması, deneyime açıklık puanlarındaki bir birimlik artışla güvenlik/istikrarın 0,141 birimlik artması ve dürüstlük puanlarındaki bir birimlik artışla güvenlik/istikrarın 0,220 beklenmektedir.

Kişilik özelliklerinin Özerklik/Otonominin anlamlı bir şekilde yordayıp yordamadıklarını tespit etmek için yapılan çoklu doğrusal regresyon analiz sonuçları Tablo 8'de verilmiştir.

Analiz sonuçlarına göre, uyumluluk ve nevrotiklik değişkenleri özerklik/otonominin anlamlı birer yordayıcısıdır ( $<<.05)$. Dışadönüklük, dürüstlük, negatif değerlik ve deneyime açıklık değişkenleri ise özerklik/otonominin anlamlı birer yordayıcısı değildir ( $\mathrm{p}>$.05). Buna göre kişilik özellikleriyle birlikte kurulan model özerklik/otonomi puanlarındaki değişimin \%08,6'sını açıklamaktadır. Özerklik/otonominin $\% 91,4$ 'ü ise araştırmaya dahil edilmeyen başka değişkenlerce açılanabilir. Tüm bu bulgular sonucunda aşağıdaki gibi regresyon modeli kurulabilir: 
Tablo 8. Kişilik Özelliklerinin Özerklik/Otonomi Üzerindeki Etkisi

\begin{tabular}{lllllllll}
\hline Bağımsız değişkenler & $\begin{array}{c}\text { B } \\
\text { katsayısı }\end{array}$ & $\mathbf{S H a}$ & $\boldsymbol{\beta}$ & $\mathbf{t}$ & $\begin{array}{c}\text { Condition } \\
\text { Index }\end{array}$ & Tolerance & VIF & p \\
\hline Sabit & 2,389 &, 215 & & 11,133 & 1,000 & &, $000^{*}$ \\
\hline Uyumluluk (U) &, 130 &, 045 &, 202 & 2,872 & 5,100 &, 614 & 1,001 &, $005^{*}$ \\
\hline Nevrotiklik (N) &, 121 &, 050 &, 171 & 2,419 & 9,029 &, 661 & 1,001 &, $017^{*}$ \\
\hline Dişadönüklük (DD) &,- 010 &, 069 &,- 012 &,- 142 & 4,483 &, 742 & 1,348 &, 887 \\
\hline Dürüstlük (D) &, 097 &, 066 &, 131 & 1,469 & 9,261 &, 626 & 1,597 &, 143 \\
\hline Negatif Değerlik (ND) &, 012 &, 051 &, 020 &, 240 & 14,534 &, 725 & 1,379 &, 811 \\
\hline $\begin{array}{l}\text { Deneyime Açıklık } \\
\text { (DA) }\end{array}$ &, 031 &, 045 &, 053 &, 686 & 18,872 &, 848 & 1,179 &, 494
\end{tabular}

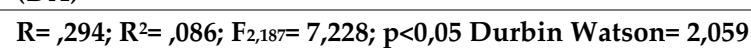

Bağımlı Değişken: Özerklik/Otonomi (Ö/O)

\section{$\ddot{O} / O=2,389+0,130 x U+0,121 x N-0,010 x D D+0,097 x D+0,012 x N D+0,031 x D A+$ hata}

Regresyon eşitliğinden görülebileceği gibi uyumluluk puanlarındaki bir birimlik artışın özerklik/otonominin 0,130 birimlik artışa ve nevrotiklik puanlarındaki bir birimlik artışın özerklik/otonominin 0,121 birimlik artışa yol açacağı söylenebilir.

Kişilik özelliklerinin girişimciliği anlamlı bir şekilde yordayıp yordamadıklarını tespit etmek için yapılan çoklu doğrusal regresyon analiz sonuçları Tablo 9'da verilmiştir.

Tablo 9. Kişilik Özelliklerinin Girişimcilik Üzerindeki Etkisi

\begin{tabular}{|c|c|c|c|c|c|c|c|c|}
\hline $\begin{array}{l}\text { Bağımsız } \\
\text { değişkenler }\end{array}$ & B katsayısı & $\mathrm{SH}_{\mathrm{a}}$ & $\beta$ & $\mathrm{t}$ & $\begin{array}{l}\text { Condition } \\
\text { Index }\end{array}$ & Tolerance & VIF & p \\
\hline Sabit & 1,363 & ,359 & & 3,797 & 1,000 & & &, $000^{*}$ \\
\hline $\begin{array}{l}\text { Dişadönüklük } \\
\text { (DD) }\end{array}$ & ,230 & ,060 & ,242 & 3,829 & 4,157 & ,943 & 1,060 &, $000^{*}$ \\
\hline Uyumluluk (U) &,- 065 & ,082 &,- 053 &,- 799 & 7,079 & 862 & 1,160 & ,425 \\
\hline $\begin{array}{l}\text { Deneyime açıklık } \\
\text { (DA) }\end{array}$ & ,367 & 057 & ,422 & 6,388 & 12,498 & 861 & 1,162 &, $000^{*}$ \\
\hline Nevrotiklik (N) &,- 050 & ,080 &,- 048 &,- 629 & 7,294 & 661 & 1,513 & ,530 \\
\hline Dürüstlük (D) &,- 029 & ,085 &,- 027 &,- 341 & 9,261 & 626 & 1,597 & ,734 \\
\hline $\begin{array}{l}\text { Negatif Değerlik } \\
\text { (ND) }\end{array}$ & ,049 & 066 & ,054 & ,741 & 14,534 & ,725 & 1,379 & 460 \\
\hline \multicolumn{9}{|c|}{$R=, 548 ; R^{2}=, 300 ; F_{3,186}=26,620 ; p<0,05$ Durbin Watson= 1,859} \\
\hline
\end{tabular}

Analiz sonuçlarına göre, dışadönüklük ve deneyime açıklık değişkenleri girişimciliğin anlamlı birer yordayıcısıdır ( $p<.05)$. Uyumluluk, nevrotiklik, dürüstlük ve negatif değerlik değişkenleri ise girişimciliğin anlamlı birer yordayıcısı olmadığı görülmüştür ( $>$ >05). Buna göre kişilik özellikleriyle birlikte kurulan model girişimcilik puanlarındaki değişimin \%30,0'unu açıklamaktadır. Girişimciliğin \%70,0'i ise araştırmaya dahil edilmeyen başka değişkenlerce açıklanabilir. Bu bulgulara göre aşağıdaki gibi regresyon modeli kurulabilir:

$$
G=1,363+0,230 x D D-0,065 x U+0,367 x D A-0,050 x N-0,029 x D+0,049 x N D+\text { hata }
$$

Regresyon eşitliğinden görülebileceği gibi dışadönüklük puanlarındaki bir birimlik artışın girişimciliği 0,230 birim artıracağı, deneyime açıklık puanlarındaki bir birimlik artışın ise girişimciliği 0,367 birim artıracağı söylenebilir. 
Kişilik özelliklerinin hizmet veya bir olaya kendini adamayı anlamlı bir şekilde yordayıp yordamadıklarını tespit etmek için yapılan çoklu doğrusal regresyon analizi sonuçları Tablo $10^{\prime}$ da verilmiştir.

Tablo 10. Kişilik Özelliklerinin Hizmet veya Bir Olaya Kendini Adamak Üzerindeki Etkisi

\begin{tabular}{|c|c|c|c|c|c|c|c|c|}
\hline Bağımsız değişkenler & B katsayısı & $\mathrm{SHa}_{\mathrm{a}}$ & $\beta$ & $\mathbf{t}$ & $\begin{array}{l}\text { Condition } \\
\text { Index }\end{array}$ & Tolerance & VIF & p \\
\hline Sabit & 2,144 & 289 & & 7,416 & 1,000 & & &, $000^{*}$ \\
\hline Uyumluluk (U) &,- 005 & 049 &,- 008 &,- 111 & 5,404 & ,776 & 1,289 & ,912 \\
\hline Dürüstlük (D) &, 084 &, 040 & 142 & 2,087 & 6,984 & ,958 & 1,044 &, $038^{*}$ \\
\hline Nevrotiklik (N) & ,286 &, 060 & ,382 & 4,793 & 10,021 & 697 & 1,435 &, $000^{*}$ \\
\hline Deneyime açıklık (DA) &,- 020 & , 053 &,- 028 &,- 384 & 15,253 & 827 & 1,209 & 702 \\
\hline Dişadönüklük (DD) & 051 & 062 & ,061 & 830 & 4,483 & ,742 & 1,348 & 408 \\
\hline Negatif Değerlik (ND) & 223 &, 046 &, 357 & 4,828 & 14,534 & ,725 & 1,379 &, $000^{*}$ \\
\hline
\end{tabular}

Bağımlı Değişken: Hizmet veya Bir Olaya Kendini Adamak (HVBOKA)

Analiz sonuçlarına göre, dürüstlük, nevrotiklik ve negatif değerlik değişkenleri hizmet veya bir olaya kendini adamanın anlamlı birer yordayıcısıdır ( $\mathrm{p}<.05)$. Uyumluluk, deneyime açıklık ve dışadönüklük değişkenleri ise hizmet veya bir olaya kendini adamanın anlamlı birer yordayıcısı olmadığı görülmüştür ( $p>$.05). Buna göre kişilik özellikleriyle birlikte kurulan model hizmet veya bir olaya kendini adama puanlarındaki değişimin \%27,3'ünü açıklamaktadır. Hizmet veya bir olaya kendini adamanın $\% 72,7^{\prime}$ si ise araştırmaya dahil edilmeyen başka değişkenlerce açıklanabilir. Tüm bu bulgular sonucunda aşağıdaki gibi regresyon modeli kurulabilir:

\section{HVBOKA $=2,144-0,005 x U+0,084 x D+0,286 x N-0,20 x D A+0,051 x D D+0,223 x N D+$ hata}

Regresyon eşitliğinden görülebileceği gibi dürüstlük puanlarındaki bir birimlik artışın hizmet veya bir olaya kendini adamayı 0,084 birim artıracağı; negatif değerlik puanlarındaki bir birimlik artışın hizmet veya bir olaya kendini adamayı 0,223 birim artıracağ ve nevrotiklik puanlarındaki bir birimlik artışın hizmet veya bir olaya kendini adamayı 0,286 birim artıracağı söylenebilir.

Kişilik özelliklerinin saf meydan okumayı anlamlı bir şekilde yordayıp yordamadıklarını tespit etmek için yapılan çoklu doğrusal regresyon analizi sonuçları Tablo 11'de verilmiştir.

Tablo 11. Kişilik Özelliklerinin Saf Meydan Okuma Üzerindeki Etkisi

\begin{tabular}{|c|c|c|c|c|c|c|c|c|}
\hline $\begin{array}{l}\text { Bağımsız } \\
\text { değişkenler }\end{array}$ & B katsayısı & $\mathrm{SH}_{\mathrm{a}}$ & $\beta$ & $t$ & $\begin{array}{l}\text { Condition } \\
\text { Index }\end{array}$ & Tolerance & VIF & $\mathrm{p}$ \\
\hline Sabit & 1,178 &, 376 & & 3,131 & 1,000 & & &, $002^{*}$ \\
\hline Uyumluluk (U) & ,279 & , 080 & ,258 & 3,460 & 6,272 & 811, & 1,233 & , $001^{*}$ \\
\hline Dürüstlük (D) & ,232 & 068 & 235 & 3,428 & 8,912 & ,961 & 1,041 &, $001^{*}$ \\
\hline $\begin{array}{l}\text { Deneyime açıklık } \\
\text { (DA) }\end{array}$ & ,062 & ,091 & , 050 & ,678 & 10,650 & 840 & 1,191 & ,498 \\
\hline $\begin{array}{l}\text { Dişadönüklük } \\
\text { (DD) }\end{array}$ & 141 & 104 & 100 & 1,351 & 4,483 & ,742 & 1,348 & ,178 \\
\hline Nevrotiklik (N) & ,262 & 094 & ,220 & 2,799 & 7,294 & ,661 & 1,513 & , $006^{*}$ \\
\hline $\begin{array}{l}\text { Negatif Değerlik } \\
\text { (ND) }\end{array}$ &,- 292 & , 078 &,- 282 & $-3,756$ & 14,534 & ,725 & 1,379 &, $000^{*}$ \\
\hline
\end{tabular}

Bağımlı Değişken: Saf Meydan Okuma (SMO) 
Analiz sonuçlarına göre, uyumluluk, nevrotiklik, negatif değerlik ve dürüstlük değişkenleri saf meydan okumanın anlamlı birer yordayıcısıdır $(\mathrm{p}<.05)$. Deneyime açıklık ve dışadönüklük değişkenlerinin ise saf meydan okumanın anlamlı birer yordayıcısı olmadığı görülmüştür ( $>$ >.05). Buna göre kişilik özellikleriyle birlikte kurulan model saf meydan okuma puanlarındaki değişimin \%25,1'ini açıklamaktadır. Saf meydan okumanın \%74,9'u ise araştırmaya dahil edilmeyen başka değişkenlerce açıklanabilir. Tüm bu bulgular sonucunda aşağıdaki gibi regresyon modeli kurulabilir:

\section{$S M O=1,178+0,279 x U+0,232 x D+0,062 x D A+0141 x D D+0,262 x N-0,292 x N D+$ hata}

Regresyon eşitliğinden görülebileceği gibi dürüstlük puanlarındaki bir birimlik artışla saf meydan okumanın 0,232 birim artacağı; nevrotiklik puanlarındaki bir birimlik artışla saf meydan okumanın 0,262 birim artataracağ1; uyumluluk puanlarındaki bir birimlik artışla saf meydan okumanın 0,279 birim artacağı anlaşılmaktadır. Diğer yandan, negatif değerlik puanlarındaki bir birimlik artışın ise saf meydan okumayı 0,292 birim azaltacağı anlaşılmaktadır.

Kişilik özelliklerinin hayat tarzını anlamlı bir şekilde yordayıp yordamadıklarını tespit etmek için yapılan çoklu doğrusal regresyon analizi sonuçları Tablo 12'de verilmiştir.

Tablo 12. Kişilik Özelliklerinin Hayat Tarzı Üzerindeki Etkisi

\begin{tabular}{|c|c|c|c|c|c|c|c|c|}
\hline Bağımsız değişkenler & $\begin{array}{c}\text { B } \\
\text { katsayısı }\end{array}$ & $\mathrm{SH}_{\mathrm{a}}$ & $\beta$ & $\mathbf{t}$ & $\begin{array}{l}\text { Condition } \\
\text { Index }\end{array}$ & Tolerance & VIF & $\mathbf{p}$ \\
\hline Sabit & 2,220 & ,211 & & 10,534 & 1,000 & & &, $000^{*}$ \\
\hline Uyumluluk (U) & 069 & 050 & , 103 & 1,364 & 7,709 & 840 & 1,190 & 174 \\
\hline Dürüstlük (D) & ,205 & 058 & ,267 & 3,540 & 8,613 & 840 & 1,190 & ,001* \\
\hline Dışadönüklük (DD) &,- 060 & 067 &,- 069 &,- 892 & 4,483 & ,742 & 1,348 & ,374 \\
\hline Nevrotiklik (N) & ,110 & 061 & , 149 & 1,817 & 7,294 & 661 & 1,513 & ,071 \\
\hline Negatif Değerlik (ND) & ,119 & 050 & , 187 & 2,375 & 14,534 & ,725 & 1,379 &, $019^{*}$ \\
\hline $\begin{array}{l}\text { Deneyime Açıklık } \\
\text { (DA) }\end{array}$ &,- 100 & 044 &,- 164 & $-2,256$ & 18,872 & 848 & 1,179 &, $025^{*}$ \\
\hline $\mathrm{R}=, 426 ; \mathrm{R}^{2}=, 182 ; \mathrm{F}_{2,187=1}$ & $0,866 \mathrm{p}<0,05$ & Irbin & Natson & 108 & & & & \\
\hline
\end{tabular}

Analiz sonuçlarına göre, dürüstlük, negatif değerlik ve deneyime açıklık değişkenleri hayat tarzının anlamlı bir yordayıcısıdır $(\mathrm{p}<.05)$. Uyumluluk, dışadönüklük ve nevrotiklik değişkenlerinin ise hayat tarzının anlamlı bir yordayıcısı olmadığ görülmüştür ( $p>.05$ ). Buna göre kişilik özellikleriyle birlikte kurulan model hayat tarzı puanlarındaki değişimin \%18,2'ini açıklamaktadır. Hayat tarzının \%81,8'i ise araştırmaya dahil edilmeyen başka değişkenlerce açıklanabilir. Bu bulgular sonucunda aşağıdaki gibi regresyon modeli kurulabilir:

$$
H T=2,220+0,069 x U+0,205 x D-0,060 x D D+0,110 x N+0,119 N D-0,100 x D A+\text { hata }
$$

Regresyon eşitliğinden görülebileceği gibi dürüstlük puanlarındaki bir birimlik artışın hayat tarzında 0,205 birim artışa ve negatif değerlik puanlarındaki bir birimlik artışın hayat tarzında 0,119 birim artışa neden olması beklenebilir. Deneyime açıklık puanlarındaki bir birimlik artışın ise hayat tarzını 0,100 birim azaltması beklenebilir.

\section{SONUÇ ve ÖNERILER}

Bireylerin kariyer çapası ve seçimine yönelik beklentilerine etki eden faktörlerin başında gelen kişilik özellikleri, iş yaşamında önemli bir yere sahiptir. Bu husus, özellikle insan faktörünün yoğun olduğu hizmet sektörlerinde kayda değer bir konudur. Hizmet sektörünün önemli bir 
kolu olan turizm sektöründe de mevcut konunun incelenmesi ve elde edilen sonuçların eğitim programlarında değerlendirilmesi oldukça önem taşımaktadır. Türkiye' de turizm meslek liseleri, turizm sektörünün nitelikli ara insan kaynağının yetiştirilmesinde büyük rol oynamaktadır. Bu nedenle araştırma T.C. Milli Eğitim Bakanlığı ve T.C. Kültür ve Turizm Bakanlığı tarafından imzalanan protokol ile pilot uygulamanın olduğu Safranbolu Evliya Çelebi Mesleki ve Teknik Anadolu Lisesinde yapılmıştır. Daha önce turizm lisesi öğrencilerinin kariyer çapalarını açılamada kişilik özelliklerinin etkisini inceleyen bir araştırmanın bulunmaması çalışmanın önemini ortaya koymaktadır. Ayrıca mevcut kanıtlar, öğrencilerin kişilik özelliklerinin kariyer çapası üzerinde etkili olduğunu ortaya koymaktadır. Bu yönüyle ilgili literatüre katkı sağlamaktadır.

Kişilik özelliklerinin nevrotiklik dışındaki tüm özelliklerinin, teknik fonksiyonel yetkinlik üzerinde anlamlı bir etkisinin olduğu, ancak teknik fonksiyonel yetkinliğin yaklaşı \% $\% 0^{\prime}$ inin araştırmaya dahil edilmeyen başka değişkenler tarafından açılanabileceği görülmüştür. Turizm sektöründe kariyer değerlerine yönelik yapılan araştırmalarda da teknik fonksiyonel yetkinliğin ön plana çıtığ görülmektedir (Türkay ve Eryılmaz, 2010; Gezen ve Köroğlu, 2014). Bu yönüyle ortaya çıkan sonuçların ilgili literatürde yer alan sonuçlarla örtüştüğü söylenebilir. Ayrıca, araştırma sonuçları uyumluluk ve nevrotikliğin özerklik/otonomi değişkeni üzerinde anlamlı etkisi olduğu, ancak özerklik/otonominin \%91,4'ünün araştırmaya dahil edilmeyen başka değişkenlerle açılanabileceği tespit edilmiştir. Bununla birlikte diğer analiz sonuçları incelendiğinde, kişilik özellikleri dışında kariyer çapaları boyutları üzerinde araştırmaya dahil edilmeyen diğer değişkenlerin açılayıcılık oranlarının \%60,9 ila \%91,4'ün arasında olduğu görülmektedir. Dolayısıyla öğrencilerin kariyer değerlerine yönelik beklentilerini açılamada, iş hayatlarına yönelik; disiplin, özveri, beklenti gibi iç faktörlerin ve çevresel, kültürel, ekonomik, sosyolojik gibi dış faktörlerin daha çok etkili olabileceğini ortaya anlaşılmaktadır. Araştırma, genel olarak kişilik özelliklerinin kariyer çapası üzerindeki anlamlı bir etkiye sahip olduğunu gösteren çalışmalarla (Jarlström, 2000; Seibert ve Kraimer, 2001; Rothmann, 2001; Schreuder ve Coetzee, 2002; Rensburg vd., 2003; Reed vd., 2004; Gunkel vd., 2010; Gökdeniz ve Merdan, 2011; Bayram ve Aytaç, 2012; Bayram vd., 2012) benzerlik taşıdığı görülmüştür. Çalışma, turizm alanından faaliyet yürüten lise öğrencilerinin kişilik özelliklerinin kariyer çapalarına etkisi olduğunu göstermektedir. Bu yönüyle ilgili literatüre katkı sağladığı düşünülmektedir.

Türkiye'de meslek liseleri dışındaki liselerin eğitim programları temel olarak öğrencileri üniversiteye hazırlık niteliğindedir. Ancak meslek liseleri, yapısı gereği bir meslek seçimine yönelik eğitim programını kapsamaktadır. Bu doğrultuda turizm meslek liseleri de turizm ve otelcilik sektöründe yer alan mesleklerin eğitimini kapsamaktadır. Dolayısıyla turizm meslek liselerinde öğrenim gören öğrencilerin kariyerlerine yönelik adımları orta öğretim programında başlamaktadır. Turizm meslek lisesi öğrencilerinin, henüz orta öğrenim aşamasındayken kişilik özelliklerinin belirlenmesi ve buna yönelik kariyer planı oluşturulması bireyin iş yaşamındaki mutluluğuna ve verimliliğine katkı sağlayacaktır. Ayrıca mutsuz ve isteksiz meslek üyelerinin turizm gelişimine olumsuz etki edeceği de unutulmamalıdır. Bu nedenle gelecekte turizm lisesi ile eğitim hayatına devam etmeyi planlayan ortaokul öğrencilerinin kişilik özellikleri tespit edilerek turizme yönelik kariyer beklentilerinin turizm meslek liseli öğrencilerinden elde edilen sonuçlarla karşılaştıılmasına yönelik çalışmaların da yapılmasında fayda olduğu düşünülmektedir.

Araştırma, turizm ve otelcilik alanında faaliyet yürüten liselerin, öğrenci seçiminde kişilik özelliklerinin önemli bir kriter olması gerektiğini ortaya koymaktadır. Dolayısıyla bu liseleri tercih eden öğrencilere mülakat sistemi kullanılarak ön test yapılması oldukça önemlidir. Böylece turizm ve otelcilik liselerinde öğrenim gören öğrencilerin kariyer değerleri oluşturma ve beklentilerini gerçekleştirmede istendik yönde gelişim sağlanmış olacaktır. 


\section{KAYNAKLAR}

Adıgüzel, Y. (2009). Shein'in Kariyer Çapaları Perspektifinde Süleyman Demirel Üniversitesi İ̈BF Öğrencilerinin Kariyer Değerlerine İlişkin Bir Araştırma. Süleyman Demirel Üniversitesi İktisadi ve İdari Bilimler Fakültesi Dergisi; 14(2), 277-292.

Arıkan, R. (2013). Araştırma Yöntem ve Teknikleri, Geliştirilmiş İkinci Basım, Ankara: Nobel Yayın.

Arnold, J. (1997). Managing Careers into the 21st Century, London: Sage Publications Inc.

Aytaç, S. (2004). İnsanı Anlama Çabası, Bursa: Ezgi Kitabevi.

Aytaç, S., (2001). Örgütsel Davranış Açısından Kişiliğin Önemi. İş, Güç, Endüstri İlişkileri ve İnsan Kaynaklart Dergisi, 3(1),139-160.

Başol, O., Duyan, E. C., ve Hilmi, E. T. C. İ. (2015). Vakıf ve Devlet Meslek Yüksekokulu Öğrencilerinin Kariyer Değerlerinin Karşılaştırılması. Ejovoc (Electronic Journal of Vocational Colleges), 5(1), 62-71.

Bayram, N., Gürsakal, S., ve Aytaç, S. (2012). Öğrencilerinin kariyer değerlerini açıklamada kişiliğin etkisi. Anadolu Üniversitesi Sosyal Bilimler Dergisi. 12(2),181-190.

Bigliardi, B., and Alberto I. D. (2009). R \& D personnel career routes: an exploratory study. Journal of Technology Management \& Innovation, 4(1), 8-21.

Bouchard, G. (2003). Cognitive appraisals, neuroticism, and openness as correlates of coping strategies: An integrative model of adaptation to marital difficulties. Canadian Journal of Behavioural Science/Revue Canadienne Des Sciences Du Comportement, 35(1), 1-12.

Costa Jr, P. T. and Widiger, T. A. (2013). Personality disorders and the five-factor model of personality. (3rd ed.). American Psychological Association. Washington https://doi.org/10.1037/13939-000

Côté, S., and Moskowitz, D. S. (1998). On the dynamic covariation between interpersonal behavior and affect: prediction from neuroticism, extraversion, and agreeableness. Journal of Personality and Social Psychology, 75(4), 1032-1046.

Danziger, N., and Valency, R. (2006). Career anchors: Distribution and impact on job satisfaction, the Israeli case. Career Development International. 11(4),293-303.

Danziger, N., Rachman-Moore, D., and Valency, R. (2008). The construct validity of Schein's career anchors orientation inventory. Career Development International. 13(1), 7-19.

Demirbilek, T. (2010). Kişilik ve Toplu Görüşme. İzmir: Dokuz Eylül Üniversitesi Matbaası.

EÇMTAL. (2020). Evliya Çelebi Mesleki ve Teknik Anadolu Lisesi, Erişim Tarihi: 10/04/2020. http://safranaotml.meb.k12.tr/icerikler/proje-okulu-bilgilendirme-toplantisi_9142233.html

Evans, C. (1996). A review of career anchors in use. European Journal of Work and Organizational Psychology, 5(4), 609-615.

Field, A. (2000). Discovering statistics using SPSS for windows. London, Thousand Oaks, Sage Publications, New Delhi.

Gençöz, T., and Öncül, Ö. (2012). Examination of Personality Characteristics in A Turkish Sample: Development of Basic Personality Traits Inventory. The Journal of General Psychology, 139(3), 194216.

George, J. M., and Zhou, J. (2001). When openness to experience and conscientiousness are related to creative behavior: an interactional approach. Journal of Applied Psychology, 86(3), 513-524. 
Gezen, T., ve Köroğlu, Ö. (2014). Turizm eğitimi alan öğrencilerin kariyer seçimine etki eden kariyer çapalarının belirlenmesine yönelik bir araştırma. Dokuz Eylül Üniversitesi Sosyal Bilimler Enstitüsü Dergisi, 16(2), 213-234.

Gökdeniz, İ., ve Merdan, E. (2011). Kişilik ile Kariyer Seçimi Arasındaki İlişkinin İncelenmesi, Aksaray Üniversitesi İktisadi ve İdari Bilimler Fakültesi Dergisi, 3(2), 23-36.

Gunkel, M., Schlaegel, C., Langella, I. M., and Peluchette, J. V. (2010). Personality and career decisiveness: An international empirical comparison of business students' career planning. Personnel Review, 39(4), 503-524.

Hazar, A. (2002). Anadolu Otelcilik ve Turizm Meslek Lisesi ile Anadolu Aşçılık Meslek Lisesi Öğretmeni Yetiştiren Eğitim Fakültelerinin Öğretmen İhtiyaçları Açısından Geliştirilmesi. (In) Turizm Eğitimi Konferansı/Workshop Kitabı (ss. 67-74).

İçerli, L., ve Uğuz Arsu, Ş. (2019). Beş Faktör Kişilik Özelliklerinin Kariyer Değerleri Üzerindeki Etkisi: Üniversite Öğrencileri Üzerine Bir Araştırma. İktisadi İdari ve Siyasal Araştırmalar Dergisi, 4(8), 21-45.

İslamoğlu, A.H. ve Alnıaçı, Ü. (2016). Sosyal Bilimlerde Araştırma Yöntemi. (Genişletilmiş 5. Baskı). İstanbul: Beta Basım Yayım Dağıtım A.Ş.

Järlström, M. (2000). Personality preferences and career expectations of Finnish business students. Career Development International. 5(3), 144-154.

Jensen-Campbell, L. A., Rosselli, M., Workman, K. A., Santisi, M., Rios, J. D., and Bojan, D. (2002). Agreeableness, conscientiousness, and effortful control processes. Journal of Research in Personality, 36(5), 476-489.

Kalaycı, Ş. (2010). SPSS Uygulamalı Çok Değişkenli İstatistik Teknikleri, Ankara: Asil Yayın Dağıtım.

Karagöz, Y. (2019). SPSS, AMOS, Meta Uygulamalı: İstatistiksel Analizler. 2. Basım. Ankara: Nobel Yayin.

Koca A., (2009). Üniversite Öğrencilerinin Değerleri ve Bireysel Özellikleri ile Kariyer Tercihleri Arasındaki İlişki: Çukurova Üniversitesi'nde Bir Araştırma, Çukurova Üniversitesi SBE, Yayınlanmamış Yüksek Lisans Tezi.

Küçüksille, E. (2018). Çoklu Doğrusal Regresyon Modeli. (Editör Şeref KALAYCI) SPSS Uygulamalı Çok Değişkenli İstatistik Teknikler (içinde). Ankara: Dinamik Akademi.

Marshall, V., and Bonner, D. (2003). Career anchors and the effects of downsizing: implications for generations and cultures at work. A preliminary investigation. Journal of European Industrial Training. 27(6), 281-291.

McAdams, D. P. (1992). The five-factor model in personality: A critical appraisal. Journal of Personality, 60(2), 329-361.

McFatter, R. M. (1994). "Interactions in predicting mood from extraversion and neuroticism." Journal of Personality and Social Psychology 66, (3). 570-578.

Milli Eğitim Bakanlığı (2015), Meslekî ve Teknik Eğitim Genel Müdürlüğü, http://mtegm.meb.gov.tr/TR/okullar.asp?PAGE=Liste, (04.04.2020).

Nakip, Mahir (2003), Pazarlama Araştırmast-Teknikler ve SPSS Destekli Uygulamalar, Ankara: Seçkin Yayım.

Olcay, A., ve Düzgün, M. (2016). Turizm Eğitimi Gören Öğrencilerin Meslek Seçimlerinin Kariyer Çapaları ile Uygunluğunun Değerlendirilmesi. Kastamonu Education Journal, 24(3), 1127-1148. 
Peterson, J., and Roger, A. (2009). Career Anchor Profiles: An Exploratory Study of Business School Participants in France. In Colloque international sur les indicateurs d'évaluation de la responsabilité sociale et environnementale des entreprises (pp. 8-10).

Pilavcı D. (2007). Bilgi Çağında Değişen Kariyer Anlayışı ve Üniversite Öğrencilerinin Kariyer Tercihlerini Etkileyen Faktörler Üzerine Bir Uygulama, Çukurova Üniversitesi SBE, Yayınlanmamış Yüksek Lisans Tezi.

Reed, M. B., M. A. Bruch and R. F. Haase, (2004). Five-Factor Model of Personality and Career Exploration, Journal of Career Assessment, 12(3), 223-238.

Rothmann, S. (2001). Die Verband tussen die Persoonlikheidsvoorkeure en Loopbaanankers van'n Groep Bestuurders. Management Dynamics: Contemporary Perspectives, 10(2), 67-89.

Schein, E. H. (1980). Career theory and research: Some issues for the future. Work, Family, and the Career: New Frontiers in Theory and Research, Praeger, New York. pp. 357-365.

Schein, E. H. (1990). Career Anchors: Discovering Your Real Values. San Diego: Pfeiffer \& Company, University Associates.

Scherer, Robert F., Luther, David C., Wiebe, Frang A., and Adams, J.S. (1988). Dimensionality of coping: factor stability using the ways of coping questionnaire, Psychological Report, 62(3), 763770.

Schreuder, A. M. G., and Coetzee, M. (2002). The relationship between career patterns and personality types. SA Journal of Industrial Psychology, 28(1), 53-59.

Seibert, S. E., and Kraimer, M. L. (2001). The five-factor model of personality and career success. Journal of Vocational Behavior, 58(1), 1-21.

Serinkan, C. ve Barutçu, E. (2006) Pamukkale Üniversitesi İ̈BF Öğrencilerinin Kariyer Planları ve Sosyotropi-Otonomi Kişilik Özelliklerine İlişkin Bir Araştırma. Afyon Kocatepe Üniversitesi İktisadi ve İdari Bilimler Fakültesi Dergisi 8(2), 317-339.

Shin, H. (2001). Career anchors: understanding differences among demographic groups at the Naval Postgraduate School. Naval Postgraduate School Monterey Master of Science in Management. Master Thesis.

Soysal, A. (2008). Çalışma yaşamında kişilik tipleri: Bir literatür taraması. Çimento İşveren Dergisi, 22(1), 4-19.

Tabachnick, B. G. and Fidell, L. S. (2001). Using Multivariate Statistics. Needham Heights: Mass. Ally and Bacon.

Tabachnick, B. ve Fidell, L. S. (2015). Çok Değişkenli İstatistiklerin Kullanımı. (Çev. Tarık TOTAN ve Mustafa BALOĞLU) 6. Basım. Ankara: Nobel Yayın.

Tamir, M. (2005). Don't worry, be happy? Neuroticism, trait-consistent affect regulation, and performance. Journal of Personality and Social Psychology, 89(3), 449-461.

Türkay, O. ve Eryılmaz, B. (2010). Kariyer değerleri ve kariyer yolu tercihleri ilişkisi: Türk turizm sektöründen örnekler. Muğla Üniversitesi Sosyal Bilimler Enstitüsü Dergisi (İLKE), 24 (Bahar): 179199.

Ülker, F. E., ve Akan, B. B. (2019) Bireylerin Bazı Kişilik Özelliklerinin Girişimci Kariyer Değerine Olan Etkisi: Önlisans Öğrencilerinin Girişimcilik Eğilimleri Üzerine Bir Araştırma. Ömer Halisdemir Üniversitesi İktisadi ve İdari Bilimler Fakültesi Dergisi, 12(2), 146-159. 
Van Rensburg, S., Rothmann, J. C., and Rothmann, S. (2003). The relationship between personality characteristics and career anchors of pharmacists. Management Dynamics: Journal of the Southern African Institute for Management Scientists, 12(3), 24-33.

Weinstock, L. M., and Whisman, M. A. (2006). Neuroticism as a common feature of the depressive and anxiety disorders: a test of the revised integrative hierarchical model in a national sample. Journal of Abnormal Psychology, 115(1), 68-74.

Wilkowski, B. M., Robinson, M. D., and Meier, B. P. (2006). Agreeableness and the prolonged spatial processing of antisocial and prosocial information. Journal of Research in Personality, 40(6), 1152-1168.

Wynne, L. A., Ferratt, T. W., and Biros, D. P. (2002, May). Career anchors of United States Air Force information systems workers: a turnover predictor?. In Proceedings of the 2002 ACM SIGCPR conference on Computer personnel research (pp. 79-89).

Yahong L., T. Xiaohong and M.Lijun, (2006). An Applied Research of the Career Anchor Theory in Scientific and Technologic Staffs in State-owned Enterprises, International Conference on Management Science and Engineering, Lille, France, 877-880 www.seiofbluemountain.com/search/detail.php?id=540. 